\title{
Agro-food SMEs' intention to adopt halal traceability system
}

\author{
${ }^{2}$ Muhamad, N.A., ${ }^{1,2,{ }^{*}}$ Kamarulzaman, N.H., and ${ }^{1}$ Nawi, N.M. \\ ${ }^{1}$ Department of Agribusiness and Bioresource Economics, Faculty of Agriculture, Universiti Putra \\ Malaysia, 43400 UPM Serdang, Selangor, Malaysia \\ ${ }^{2}$ Halal Products Research Institute, Universiti Putra Malaysia, 43400 UPM Serdang, Selangor, \\ Malaysia
}

\begin{abstract}
Article history:
Received: 29 August 2019

Received in revised form: 21

October 2019

Accepted: 3 November 2019

Available Online: 10

February 2020
\end{abstract}

Keywords:

Agro-food SMEs,

Adoption,

Intention,

Halal,

Traceability system

DOI:

https://doi.org/10.26656/fr.2017.4(S1).S28

\begin{abstract}
Traceability system enables agro-food small and medium enterprises (SMEs) to record the information on attributes of their products along the food supply chain effectively. The halal status of the food products can be retained across companies' supply chain by practising halal traceability system. This system is considered as one of the advanced technologies to overcome the violation of halal food products in the market despite low usage of advanced technologies detected among Malaysian SMEs. The main objective of the study was to investigate the agro-food SMEs' intention to adopt halal traceability system. This study involved 130 agro-food SMEs that were selected using a systematic random sampling method. A structured questionnaire was used to collect the data from the SMEs. The data were analyzed using descriptive analysis, mean ranking analysis, Chisquare analysis, and independent-samples t-test. The results revealed that majority of agro -food SMEs involved in this study (111 companies, 85.4\%) were categorized as small business size companies and most of the agro-food SMEs (73 companies, 56.2\%) was in operation for less and equal to 9 years in the agro-food industry. Based on the mean ranking analysis, the agro-food SMEs have high intention to adopt halal traceability system (mean score of 4.25). From the Chi-square analysis result, there was a significant association between sales turnover and agro-food SMEs' intention to adopt halal traceability system $(\mathrm{p}=0.046)$. This explained that the agro-food SMEs with low sales turnover tend to have high intention to adopt halal traceability system in order to upgrade their businesses. Independent-samples $t$-test revealed that there was a significant difference between sales turnover of low and high intention of agro-food SMEs to adopt halal traceability system; $\mathrm{t}(128)=1.964, \mathrm{p}=0.052$. This study concluded that the agrofood SMEs should be encouraged and exposed to the adoption of advanced technologies in the market.
\end{abstract}

\section{Introduction}

According to Department of Statistics Malaysia (DOSM) (2017), the annual growth of small and medium enterprises (SMEs) value-added in the manufacturing sector showed a rise of $6.8 \%$ in 2017 from $4.8 \%$ in 2016 . Food, beverages, and tobacco subsectors led the increment of $11.0 \%$ in 2017 compared to $2.9 \%$ in 2016 . These statistics explain the expansion of food, beverages, and tobacco subsectors in SMEs. The SMEs have dominated Malaysian food industry which is commonly based on cultures and Asian tastes. The constant and rapid development of Malaysian food and beverage industry are becoming an appealing sector for the entrepreneurs. According to the Ministry of International
Trade and Industry Malaysia (MITI) (2017), approximately $10 \%$ of Malaysian's manufacturing output was represented by Malaysian-owned firm SMEs. Nowadays, the demand for healthy and safe food has increased as Malaysian consumers are aware and becoming more health-conscious. Hence, the Malaysian halal industry provides a great opportunity for Malaysian producers and manufacturers especially SMEs. This is because halal food production requires producers and manufacturers to produce Shariah-compliance food which also assures the hygiene and safety of the products (Shafii and Khadijah, 2011). This is advantageous to the market share as most of the population in Malaysia are Muslim consumers and Malaysia could step in and fulfil the demand for halal products for the country. 
However, there is a huge concern among consumers regarding the violation of halal food products, which requires great consideration by the food manufacturers and producers. Muslim consumers tend to be attentive in assessing their dietary consumption that concerns the obligation towards religion given the sensitivity of halal issues among Muslim consumers. In 2018, several companies were reported to use fake halal logos on their food products, raising doubts and queries among Muslim consumers regarding halal compliance and halal integrity among halal industry players and the effectiveness of halal food traceability system in the Malaysian market (Nuar, 2018; Othman, 2018; Yahya, 2018). Therefore, an effective traceability system is important to prevent the recurrence of such issues (Zailani et al., 2010; Shafii and Khadijah, 2011; Poniman et al., 2012; Mohamed et al., 2016). Furthermore, halal traceability system could enhance halal transparency along the food supply chain and hence, fostering trust among consumers towards food consumption. With the availability of halal traceability system, the halal status of the food products can be retained across the companies supply chain, which is also one of the important elements in halal supply chain management. Therefore, in order to perpetuate the product information and the halal status along the supply chain, a fully integrated supply chain is crucial to ensure both inbound and outbound logistics are concurrent with the halal traceability system (Ahmad Tarmizi et al., 2014; Usman et al., 2018).

However, the adoption of advanced systems by most of the SMEs in Malaysia such as intranet, extranet, ecommerce marketplace and Customer Relationship Management (CRM) systems, in which their level of complexity is equal as the traceability system are still low despite extensive utilization of computers, smartphones, and the internet in business management (SME Corp Malaysia, 2017). The small and medium enterprises (SMEs) in Malaysia are basically afflicted by immense retrogression because they are not ready to face the forthcoming challenges (Thurasamy et al., 2009). These issues arise because of the hassles faced by SMEs in adopting new technologies as they have a weak technological base, limited utilization of information technologies, and lack of workforce (Chin et al., 2012).

In a nutshell, the violation of the halal food products along the supply chain by the producers and manufacturers in the food industry had triggered a serious concern among consumers. Granted that Muslim consumers made up most of the population in Malaysia, they tend to be more sensitive in their choice of consumption. Manufacturers and producers, particularly SMEs must take these issues seriously if they want to retain and regain the customers, as well as strengthening the market share. Therefore, the concern is whether there are barriers that cause the low adoption of these systems that will affect their intention to implement the halal traceability system.

In light of the above discussion, the main objective of the study was to investigate the agro-food SMEs' intention to adopt halal traceability system. The three specific objectives were 1) to identify the level of agrofood SMEs' intention to adopt halal traceability system, 2) to determine the association between firmographic profiles of agro-food SMEs and their intention to adopt halal traceability system, and 3) to determine the difference between sales turnover of low and high intention of agro-food SMEs to adopt halal traceability system. By achieving the stated objectives, this study would provide and facilitate agro-food SMEs resolution to enhance their efficiency in managing the business, as well as improving their effectiveness in handling and adopting halal traceability system.

\section{Methodology}

A sample of 130 halal-certified agro-food SMEs was obtained by using Krejcie and Morgan Table (Krejcie and Morgan, 1970) in which represent the total population as referred to Halal Industry Development Corporation (HDC). Data collection was conducted throughout Peninsular Malaysia at the beginning of January 2019 until the end of April 2019. A systematic random sampling method was used to identify the respondents as they were selected based on the data provided by the Department of Islamic Development Malaysia (JAKIM). Primary data was utilized using a structured questionnaire as a research instrument. The questionnaire was developed in the form of closed-ended questions with positive and straightforward statements to avoid any misunderstanding during the survey and to ensure a quick response from the respondents. The questions regarding agro-food SMEs' intention to adopt halal traceability system were developed in a 5-point Likert Scale where 1 is "strongly disagree"; 2 is "disagree"; 3 is "neutral"; 4 is "agree"; and 5 is "strongly agree". Several analyses such as descriptive analysis, mean ranking analysis, Chi-square analysis, and independent-samples t-test were used to analyse the data. The conceptual framework established for this study is depicted in Figure 1.

\section{Results and discussion}

\subsection{Firmographic profiles}

The descriptive analysis was used to illustrate the basic characteristics of data in which the firmographic profiles of agro-food SMEs where the size of the 


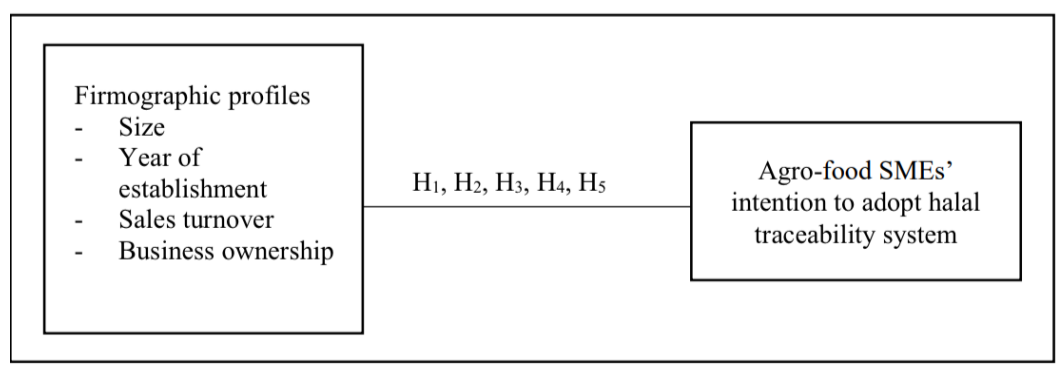

Figure 1. Conceptual framework of agro-food SMEs' intention to adopt halal traceability system. Source: Adapted from Nugroho et al. (2017); Das and Das (2012); Mhenni et al. (2011); Stiglitz (2006); Fishbein and Ajzen (1975)

Table 1. Summary of SME definition

\begin{tabular}{ccc}
\hline & Manufacturing & Services and Other \\
\hline \multirow{4}{*}{ Medium } & Sales turnover: & Sales turnover: \\
& RM15 mil $\leq$ RM50 mil & RM3 mil $\leq$ RM20 mil \\
& OR & OR \\
& Employees: & Employees: \\
& From 75 to $\leq 200$ & From 30 to $\leq 75$ \\
\hline \multirow{3}{*}{ Small } & Sales turnover: & Sales turnover: \\
& RM300,000 $<$ RM15 mil & RM300,000 $<$ RM3 mil \\
& OR & OR \\
& Employees: & Employees: \\
& From 5 to $<75$ & From 5 to $<30$ \\
\hline \multirow{2}{*}{ Micro } & Sales turnover: & Sales turnover: \\
& $<$ RM300,000 & $<$ RM300,000 \\
& OR & OR \\
\hline Source & Employees: $<5$ & Employees: $<5$ \\
\hline
\end{tabular}

Source: SME Corp. Malaysia (2015)

company, year of establishment, sales turnover, and legal status were analyzed. The results showed that out of 130 agro-food SMEs that involved in this study, 111 companies $(85.4 \%)$ were categorized as small size, 13 companies $(10.0 \%)$ were the micro size and the remaining 6 companies $(4.6 \%)$ were categorized into medium size. The size was classified according to the definition established by SME Corporation Malaysia (Table 1). This study also revealed that 60 companies $(46.2 \%)$ were sole proprietor, whereas 57 companies (43.8\%) and 10 companies $(7.7 \%)$ were categorized as private limited and partnership, respectively. The remaining three companies $(2.3 \%)$ were categorized as others. Sales turnover which was categorized according to SME definition (Table 1) indicated that 72 agro-food SMEs $(55.4 \%)$ have gained less than RM300,000 per year while $57(43.8 \%)$ and one $(0.8 \%)$ of agro-food SMEs have gained RM300,000 to RM14.9 million and RM15 million to RM50 million, respectively. The results also indicated that most of SMEs (56.2\%) were categorized as short-term companies as they have been in the operation of the agro-food industry for less and equal to 9 years. Further, the adoption of advanced systems by most of agro-food SMEs were still low where 25 SMEs used barcode scanner (19.23\%); 17 SMEs used inventory counter $(13.08 \%)$ despite the extensive utilisation of computers $(\mathrm{n}=99,76.15 \%)$, mobile phones $(\mathrm{n}=126$, $96.92 \%)$, and the Wi-Fi $(\mathrm{n}=50,38.46 \%)$ as their communication and record-keeping tools. This indicates that agro-food SMEs were lagging far behind from using any type of traceability system aforementioned by Meuwissen et al. (2003) and also devices (RFID) as suggested by Zailani et al. (2010). Table 2 summarizes the results obtained from the descriptive analysis.

Table 2. Firmographic profiles

\begin{tabular}{|c|c|c|c|}
\hline & & $\begin{array}{l}\text { Frequency } \\
\text { (n) }\end{array}$ & $\begin{array}{c}\text { Percentage } \\
(\%)\end{array}$ \\
\hline \multirow{3}{*}{ Size } & Medium & 6 & 4.6 \\
\hline & Small & 111 & 85.4 \\
\hline & Micro & 13 & 10 \\
\hline \multirow{2}{*}{$\begin{array}{c}\text { Year of } \\
\text { establishment }\end{array}$} & $\leq 9$ years & 73 & 56.2 \\
\hline & $>9$ years & 57 & 43.8 \\
\hline \multirow{3}{*}{ Sales turnover } & $\begin{array}{l}\text { RM15 million } \leq \\
\text { RM50 million }\end{array}$ & 1 & 0.8 \\
\hline & $\begin{array}{l}\text { RM300,000 < } \\
\text { RM15 million }\end{array}$ & 57 & 43.8 \\
\hline & $<\mathrm{RM} 300,000$ & 72 & 55.4 \\
\hline \multirow{4}{*}{$\begin{array}{l}\text { Business } \\
\text { ownership }\end{array}$} & Sole proprietor & 60 & 46.2 \\
\hline & Partnership & 10 & 7.7 \\
\hline & Private limited & 57 & 43.8 \\
\hline & Others & 3 & 2.3 \\
\hline \multirow{5}{*}{$\begin{array}{c}\text { Types of tools } \\
\text { used }\end{array}$} & Mobile phone & 126 & 96.92 \\
\hline & Computer & 99 & 76.15 \\
\hline & Wi-Fi & 50 & 38.46 \\
\hline & Bar code scanner & 25 & 19.23 \\
\hline & Inventory counter & 17 & 13.08 \\
\hline
\end{tabular}

Source: SME Corp. Malaysia (2015)

\subsection{Level of agro-food SMEs' intention to adopt Halal traceability system}

The mean ranking analysis was carried out to analyse the level of agro-food SMEs' intention to adopt halal traceability system in their business. Table 3 summarizes the mean score analysis. The eight statements responded by the respondents based on 5point Likert scales were analysed where the result revealed the average mean score computed was 4.25. The low average standard deviation of 0.648 indicated that the data points were spread close to the mean. In this study, the scale was split into high and low intention in which the mean score of 4.00 and above was considered 
Table 3. Mean ranking analysis of agro-food SMEs' intention to adopt halal traceability system

\begin{tabular}{lcc}
\hline \multicolumn{1}{c}{ Items } & Mean & Standard deviation \\
\hline 1. We intend to adopt halal traceability system as the profit gains by the firm is expected to be & 4.32 & 0.705 \\
2. We have a high intention to use halal traceability system in our firm. & 4.28 & 0.671 \\
3. We plan to use halal traceability system to manage our business. & 4.26 & 0.665 \\
4. We intend to learn about using halal traceability system. & 4.26 & 0.629 \\
5. We intend to adopt halal traceability system. & 4.25 & 0.585 \\
6. We will take initiative to adopt halal traceability system in the future. & 4.22 & 0.613 \\
7. We would use halal traceability system rather than the old method to trace the products. & 4.15 & 0.622 \\
8. We predict that we would use halal traceability system in the future. & Average mean score and standard deviation & 4.25 \\
\hline
\end{tabular}

as a high level of intention whereas the mean score below 4.00 was considered as a low level of intention. This is in line with the intention scales suggested by Maffei et al. (2012). Thus, based on the mean ranking analysis, the results indicated that 103 agro-food SMEs have a high intention while 27 agro-food SMEs have a low intention to adopt halal traceability system in managing their business (Table 4 ). The result was in line with a study by Ngah and Ramayah (2018) who revealed perceived benefits has a positive relationship with the intention to adopt halal transport services as the higher the perceived benefits, the higher the intention to adopt halal transport services.

Table 4. Level of agro-food SMEs' intention to adopt halal traceability system

\begin{tabular}{ccc}
\hline Mean score & Frequency $(\mathrm{n})$ & Percentage $(\%)$ \\
\hline High $(4-5)$ & 103 & 20.8 \\
Low (1-3.99) & 27 & 79.2 \\
\hline
\end{tabular}

3.3 Association between firmographic profiles and agrofood SMEs' intention to adopt halal traceability system

Chi-square analysis was used to identify the association between two nominal variables as it compares the expected value with the actual value of the data. This analysis was carried out to achieve the first objective of the study which was to study the association between firmographic profiles and agro-food SMEs' intention to adopt halal traceability system. The hypotheses that were tested for this analysis are as follows: -

$\mathrm{H}_{1}$ : Size has an association with agro-food SMEs' intention to adopt halal traceability system.

$\mathrm{H}_{2}$ : Year of the establishment has an association with agro-food SMEs' intention to adopt halal traceability system.

$\mathrm{H}_{3}$ : Sales turnover has an association with agro-food SMEs' intention to adopt halal traceability system.

$\mathrm{H}_{4}$ : Business ownership has an association with agrofood SMEs' intention to adopt halal traceability system.
Table 5 shows that only sales turnover has a significant association with agro-food SMEs' intention to adopt halal traceability system with significant value of 3.976, $(\mathrm{p}=0.046)$. Thus, the $\mathrm{H}_{0}$ was rejected. The result seemed to accord with findings by Hassan et al. (2017) where SMEs with additional resources projected for the information technology (IT) and are under pressure from the competitors tend to adopt cloud computing. This showed that sales turnover is one of the factors that influenced the intention of the organization to adopt new technology. In this study, the respondents from micro and small size agro-food SMEs were reluctant to adopt new technology particularly halal traceability system because of limited resources. The result revealed that sales turnover was the contributing factor to agro-food SMEs' intention to adopt halal traceability system. Apart from that, other variables such as the size, year of establishment, and business ownership were not significant, indicating that the variables did not have associations with agro-food SMEs' intention to adopt halal traceability system. Thus, the $\mathrm{H}_{0}$ failed to reject.

Table 5. Result of chi-square test between firmographic profiles and agro-food SMEs' intention to adopt halal traceability system

\begin{tabular}{lcccc}
\hline \multicolumn{1}{c}{$\begin{array}{c}\text { Firmographic } \\
\text { profiles }\end{array}$} & Value & df & $\begin{array}{c}\text { Asymp Sig. } \\
(2 \text { sided })\end{array}$ & Decision \\
\hline Size & 1.976 & 2 & 0.372 & Fail to reject \\
Year of & 0.256 & 1 & 0.613 & Fail to reject \\
Sales turnover & $\mathbf{3 . 9 7 6}$ & $\mathbf{2}$ & $\mathbf{0 . 0 4 6 * *}$ & Reject $\mathrm{H}_{0}$ \\
Business ownership & 1.664 & 3 & 0.645 & Fail to reject \\
\hline
\end{tabular}

$* *$ Significant at $5 \%$ level of significance

3.4 Comparison between sales turnover of low and high intention of agro-food SMEs to adopt halal traceability system

The hypotheses that were tested are as follows: -

$\mathrm{H}_{0}$ : There is no difference between the sales turnover of the low and high intention of agro-food SMEs to adopt halal traceability system. 
$\mathrm{H}_{5}$ : There is a difference between the sales turnover of the low and high intention of agro-food SMEs to adopt halal traceability system.

This analysis focused on sales turnover as it was the only factor that revealed a significant association with agro-food SMEs' intention to adopt halal traceability system. Independent-samples t-test was used in comparing the mean score of two different groups of condition towards a continuous variable. In this study, two different groups of the condition were referred to low and high intention of agro-food SMEs to adopt halal traceability system, whereas the continuous variable was referred to sales turnover. Table 6 shows that low intention adopters $(n=27)$ have a high score of sales turnover (RM8,065,777.78) compared to high intention adopters $(n=103)$ which have a low score of sales turnover (RM697,908.74). The use of technology and its advancements could hike up the sales of the company as enormous information about the market could be easily accessed (Anderson and Bolton, 2015). This explained the results revealed from the analysis that the agro-food SMEs with low sales turnover tend to have high intention to adopt halal traceability system in order to upgrade their businesses. Thus, the agro-food SMEs could generate higher income, customers are within reach and improve the systematic management system. Contrary, the agro-food SMEs with high sales turnover were reluctant to adopt the halal traceability system as they were already well established and could generate high income without having to adopt the system in their business.

Table 6. Mean and standard deviation of sales turnover

Intention $\quad \mathrm{n} \quad$ Mean $\quad \begin{gathered}\text { Standard } \\ \text { Deviation }\end{gathered}$

Sales turnover Low intention $27 \quad 8,065,777.78 \quad 38365321.4$ (RM)

High intention $103 \quad 697,908.74 \quad 1597346.43$

Levene's test for equality variance in Table 7 shows that the significant value is less than $0.05(\mathrm{p}=0.000)$, indicating the equal variances were not assumed and that the variance of the two different groups is proven not the same. The t-test for equality means showed that there was a significant difference between the two groups as the value in Sig. (2-tailed) was equal to 0.52 . The result further indicated that there was a significant difference in scores for the low and high intention to adopt halal traceability system among agro-food SMEs; $\mathrm{t}(128)=$ $1.964, \mathrm{p}=0.052$. Thus, the $\mathrm{H}_{0}$ was rejected.

\section{Conclusion}

Based on the result, agro-food SMEs have high intention to adopt halal traceability system. Besides, this study also showed that sales turnover has a significant association with agro-food SMEs' intention to adopt halal traceability system. It can be said that sales turnover influenced the intention of agro-food SMEs to adopt halal traceability system. Furthermore, there was a significant difference in scores for the low and high intention of agro-food SMEs to adopt halal traceability system. This study concludes that increase exposure to technological advances among agro-food SMEs in Malaysia and encouragement could improve their intention to adopt the technologies. The government should intensify their effort by educating them through seminar or workshop on how to grab opportunities of technological advances in the market and provide the financial support for their business as to help them in adopting the technologies among the micro and smallsized agro-food SMEs.

\section{Acknowledgement}

We thank the Ministry of Education Malaysia (MOE) for the financial support through the Malaysian Higher Education Consortium of Halal Institute (KIHIM); Vote No: 6300912.

\section{References}

Ahmad Tarmizi, H., Kamarulzaman, N.H., Abd Latif, I. and Abd Rahman, A. (2014). Factors behind thirdparty logistics providers' readiness towards halal logistics. International Journal of Supply Chain Management, 3(2), 53-62.

Anderson, M. and Bolton, J. (2015). Integration of sensors to improve customer experience: Implementing device integration for the retail sector, presented at the 2015 IEEE 12th International Conference on e-Business Engineering, 23-25 October 2015. Beijing: IEEE. https:// doi.org/10.1109/ICEBE.2015.71

Chin, T.A., Hamid, A.B.A., Rasli, A. and Baharun, R. (2012). Adoption of supply chain management in

Table 7. Independent-Samples T-Test

\begin{tabular}{ccccccc}
\hline & $\begin{array}{c}\text { Levene's Test for Equality of } \\
\text { Variances }\end{array}$ & \multicolumn{3}{c}{ t-test for Equality of Means } \\
\hline & $\mathrm{F}$ & Sig. & $\mathrm{t}$ & $\mathrm{df}$ & \multicolumn{1}{c}{ Sig. (2-tailed) } \\
\hline Sales turnover (RM) Equal variances assumed & 14.872 & $.000^{* * *}$ & 0.998 & 26.024 & 0.328 \\
Equal variances not assumed & & & 1.964 & 128 & $.052^{* *}$ \\
\hline
\end{tabular}

***Significant at $1 \%$ level of significance, ${ }^{* *}$ Significant at $5 \%$ level of significance. 
SMEs. Procedia-Social and Behavioral Sciences, 65, 614-619. https://doi.org/10.1016/ j.sbspro.2012.11.173

Das, S. and Das, K.K. (2012). Factors influencing the information technology adoption of micro, small and medium enterprises (MSME): An empirical study. International Journal of Engineering Research and Applications, 2(3), 2493-2498.

Department of Statistics Malaysia. (2017). Annual growth of SME value-added in manufacturing sector.

Fishbein, M. and Ajzen, I. (1975). Beliefs, Attitude, Intention and Behavior: An Introduction to Theory and Research, Reading, MA: Addison Wesley.

Hassan, H., Nasir, M.H.M., Khairudin, N and Adon, I. (2017). Factors influencing cloud computing adoption in small and medium enterprises. Journal of Information and Communication Technology (JICT), 1, 21-41.

Krejcie, R.V. and Morgan, D.W. (1970). Determining Sample Size for Research Activities. Educational and Psychological Measurement, 30, 607-610. https://doi.org/10.1177/001316447003000308

Maffei, R.M., Dunn, K. and Zhang, J., Hsu, C.E. and Holmes, J.H. (2012). Understanding Behavioral Intent to Participate in Shared Decision-Making in Medically Uncertain Situations. Methods of Information in Medicine, 51(4), 301-308. https:// doi.org/10.3414/ME11-01-0077

Meuwissen, M., Velthuis, A., Hogeveen, H. and Huirne, R.B.M. (2003). Traceability and certification in meat supply chains. Journal of Agribusiness, 21, 167-181.

Mhenni, H., Youssef, A. and Walid, H. (2011). Intrafirm diffusion of innovation: Evidence from Tunisian SMEs regarding information and communication technologies. Middle East Development Journal, 3, 75-97. https:// doi.org/10.1142/S1793812011000338

Ministry of International Trade and Industry Malaysia (MITI). (2017). MITI report 2018. Retrieved on 20 August 2019 from MITI website: https:// www.miti.gov.my/miti/resources/MITI\%20Report/ MITI_Report_2018.pdf

Mohamed, Y.H., Rahim, A.R.A., Ma'ram, A. and Hamza, M.G. (2016). Halal traceability in enhancing halal integrity for food industry in Malaysia. International Research Journal of Engineering and Technology, 3(3), 68-74.

Ngah, A. and Ramayah, T. (2018). Modelling the intention to adopt halal transportation among halal pharmaceutical and cosmetic manufacturers in Malaysia. Advanced Science Letters, 24, 205-207. https://doi.org/10.1166/asl.2018.11960

Nuar, K.A. (2018, 5 January). Keropok udang logo halal meragukan dirampas. Utusan Online. Retrieved on
26 August 2019 from http://www.utusan.com.my/ berita/terkini/keropok-udang-logo-halal-meragukandirampas-1.585201

Nugroho, M.A., Susilo, A.Z., Fajar, M.A. and Rahmawati, D. (2017). Exploratory study of SMEs technology adoption readiness factors. Procedia Computer Science, 124, 329-336. https:// doi.org/10.1016/j.procs.2017.12.162

Othman, F.S. (2018, July 27). Kilang makanan ringan pamer logo halal palsu diserbu. Retrieved on 20 August 2019 from Berita Harian Online: https:// www.bharian.com.my/berita/kes/2018/07/454545/ kilang-makanan-ringan-pamer-logo-halal-palsudiserbu. [In Bahasa Malaysia].

Poniman, D., Purchase, S. and Sneddon, J. (2015). Traceability systems in the Western Australia halal food supply chain. Asia Pacific Journal of Marketing and Logistics, 27(2), 324-348. https:// doi.org/10.1108/APJML-05-2014-0082

Shafii, Z. and Khadijah, W.S. (2011). Halal traceability framework for halal production. World Applied Science Journal, 15, 1-5.

Stiglitz, J.E. (2006). Making globalisation work. New York, USA: W.W. Norton and Company, Inc.

SME Corp. Malaysia (2015). SME definitions. Retrieved from SME Corp website: http:// www.smecorp.gov.my/index.php/en/policies/201512-21-09-09-49/sme-definition

SME Corp. Malaysia. (2017). SME Annual Report 2017/2018. Retrieved on 5 June 2019 from SME Corp website: http://www.smecorp.gov.my/images/ SMEAR/SMEAR2017/ENG/

Chapter2BoxArticle2.pdf

Ramayah, T., Mohamad, O., Omar, A. and Marimuthu, M. (2009). Technology adoption among small and medium enterprises (SME's): A research agenda. World Academy of Science, Engineering and Technology, 53, 943-946.

Usman, Y.V., Fauzi, A.M., Irawadi, T.T. and Diatna, T. (2018). Augmented halal food traceability system: analysis and design using UML. IOP Conference Series: Materials Science and Engineering, 337, 1-7. https://doi.org/10.1088/1757-899X/337/1/012050

Yahya, O. (2018). 10 tahun guna logo halal palsu. Retrieved on 15 August 2019 from Kosmo Online: http://www.kosmo.com.my/negara/10-tahun-gunalogo-halal-palsu-1.587690 . [In Bahasa Malaysia].

Zailani, S., Arrifin, Z., Wahid, N.A., Othman, R. and Fernando, Y. (2010). Halal traceability and halal tracking system in strengthening halal food supply chain for food industry in Malaysia. Journal of Food Technology, 8(3), 74-81. https://doi.org/10.3923/ jftech.2010.74.81 